\title{
Evaluation of the performance of micromoulding blocks using micromanufacturing technologies
}

\author{
Vasco, J.C. ${ }^{a, b,}$, , Ferreira, I.S. ${ }^{b}$, Pouzada, A.S. ${ }^{a}$ \\ anstitute for Polymers and Composites/I3N, University of Minho, Guimarães, Portugal \\ ${ }^{b}$ Department of Mechanical Engineering, Polytechnic Institute of Leiria, Portugal
}

\begin{abstract}
A B S T R A C T
The production of micromoulding blocks for the mass production of plastic microparts is associated to the decision of the more adequate micromanufacturing technology for the quickest time to moulding operation. The integration of subtractive and additive micro manufacturing technologies and micromoulding techniques made the development of plastics microcomponents in several domains of activity possible at feasible costs. However, the lifetime expectancy of their replication tools is directly dependent on the tool material properties and the thermal and mechanical characteristics of moulding process. Besides the tool manufacturing costs, post-treatments to achieve the enhancement of tool properties as surface roughness or abrasion resistance must also be considered, so that the mass production process results technically and economically effective. Thus, a trade-off is required to establish the break-even point between the overall tool cost and the tool lifetime. An analysis was made on the design of plastics microparts considering their performance requirements and implications on the tooling manufacturing route and expected production life. It was considered the use of additive and subtractive technologies for the microtooling manufacture using current industrial equipment. This study enabled a possible approach using the Analytical Hierarchical Process (AHP) towards the detailed analysis of the life cycle and production costs of common routes in microinjection moulding. A study of this type requires the continuous update of micromanufacturing technological developments in order to score actual process features. This analytical hierarchization approach enables decision makers to input market requirements and to obtain suitable manufacturing solutions, considering the continuous technological challenges and economical aspects.
\end{abstract}

\section{ARTICLE INFO \\ Keywords: \\ Microinjection \\ Micromanufacturing \\ Economical feasibility \\ *Corresponding author: joel.vasco@ipleiria.pt \\ (Vasco, J.C.)}

(C) 2013 PEI, University of Maribor. All rights reserved.

\section{References}

[1] Martyn, M.T, Whiteside, B., Coates, P.D., Allan, P.S., Greenway, G., Hornsby, P. (2003). Micromoulding: consideration of processing effects on medical materials, In: Proceedings of ANTEC 2003 - 61 ${ }^{\text {st }}$ Annual Technical Conference, Nashville, 2582-2586.

[2] Giboz, J., Copponnex, T., Mele, P. (2007). Microinjection molding of thermoplastic polymers: a review, Journal of Micromechanic and Microengineering, Vol. 17, No. 6, 96-109, doi: 10.1088/0960-1317/17/6/r02.

[3] Zhao, J., Mayes, R.H., Chen, G.E., Xie, H., Chan, P.S. (2003). Effects of process parameters on the micro molding process, Polymer Engineering and Science, Vol. 43, No 9, 1542-1554.

[4] Dimov, S.S., Mathews, C.W., Glanfield, A., Dorrington, P. (2006). A roadmapping study in multi-material micro manufacture, In: Proceedings of The Second International Conference on Multi-Material Micro Manufacture, 4M2006, Grenoble, France, xi-xxv. 
[5] Vasco, J.C., Selada, A., Neves, T., Pouzada, A.S. (2010). A study on the mouldability of POM microdetails in moulding blocks using micromanufacturing technologies, In: Proceedings of PMI - Polymer and Mould Innovations, Ghent, Belgium.

[6] Popov, K., Dimov, S., Pham, D., Minev, R., Rosochowski, A., Olejnik, L. (2006). Micromilling: material microstructure effects, Proceedings of the Institution of Mechanical Engineers, Part B: Journal of Engineering Manufacture, Vol. 220, No. 11, 1807-1813.

[7] Popov, K., Dimov, S., Ivanov, A., Pham, D., Gandarias, E. (2010). New tool-workpiece setting up technology for micro-milling, The International Journal of Advanced Manufacturing Technology, Vol. 47, No. 1, 21-27, doi: 10.1007/s00170-009-2055-2.

[8] Gietzelt, T., Eichhorn, L., Schubert, K. (2008). Manufacturing of microstructures with high aspect ratio by micromachining, Microsystem Technologies, Vol. 14, No. 9, 1525-1529, doi: 10.1007/s00542-007-0535-6.

[9] Jackson, M.J. (2007). Micro and nanomanufacturing, Springer, New York.

[10] Pham, D.T., Dimov, S.S., Petkov, P.V., Dobrev, T. (2005). Laser Milling for Micro Tooling, In: Proceedings of VIII LAMDAMAP Conference, Cranfield, 362-371.

[11] Descoeudres, A. (2006). Characterization of electrical discharge machining plasmas, PhD thesis, École Polytecnique Fédérale de Lausanne.

[12] Vanderauwera, W., Garzon, M., Aerts, T., Klocke, F., Lauwers, B. (2011). Comparison of micro-milling and microEDM operations, In: Proceedings of the $8^{\text {th }}$ International Conference on Multi-Material Micro Manufacture, Aachen, 285-289.

[13] Rajurkar, K., Madou, M. (2005). Processes, In: WTEC (ed.), WTEC panel report on international assessment of research and development in micromanufacturing, 39-64.

[14] Bourell, D., Rajurkar, K. (2005). Materials, In: WTEC (ed.), WTEC panel report on international assessment of research and development in micromanufacturing, 21-38.

[15] Bertsch, A., Jiguet, S., Bernhards, P., Renaud, P. (2003). Microstereolitography: a review, In: Proceedings of Materials Research Society Symposium 758, Materials Research Society.

[16] Koster, R., Ragaert, K. (2007). Bioplastics injection moulding and modern mould opportunities, In: Proceedings of the $2^{\text {nd }}$ Polymers \& Moulds Innovations Conference, Ghent, Belgium.

[17] Ribeiro, A.S., Hopkinson, N., Ahrens, C.H. (2004). Thermal effects on stereolithography tools during injection moulding, Rapid Prototyping Journal, Vol. 10, No. 3, 176-180, doi: 10.1108/13552540410538996.

[18] Kruth, J.-P., Vandenbroucke, B., Van Vaerenbergh, J., Mercelis, P. (2005). Benchmarking of different SLS/SLM processes as rapid manufacturing techniques, In: Proceedings of the $1^{\text {st }}$ Polymers \& Moulds Innovations Conference, Ghent, Belgium.

[19] Selada, A., Manaia, A., Vieira, M., Pouzada, A. (2011). Effect of LBM and large-area EBM finishing on microinjection moulding surfaces, The International Journal of Advanced Manufacturing Technology, Vol. 52, No. 1, 171-182, doi: 10.1007/s00170-010-2723-2.

[20] Uno, Y., Okada, A., Uemura, K., Raharjo, P., Sano, S., Yu, Z., Mishima, S. (2007). A new polishing method of metal mold with large-area electron beam irradiation, Journal of Materials Processing Technology, Vol. 187-188, 77-80, doi: 10.1016/j.jmatprotec.2006.11.080.

[21] Neto, V.F., Vaz, R., Ali, N., Oliveira M.S.A., Grácio, J. (2008). Diamond coatings on 3D structured steel, Diamond and Related Materials, Vol. 17, No. 7-10, 1424-1428.

[22] Yasa, E., Deckers, J., Craeghs, T., Badrossamay, M., Kruth, J.-P. (2009). Investigation on occurrence of elevated edges in SLM, In: Proceedings of the $20^{\text {th }}$ Solid Freeform Fabrication (SFF) Symposium, Austin, Texas, USA.

[23] Chuang, P.T. (2001). Combining the analytical hierarchy process and quality function deployment for a location decision from a requirement perspective. International Journal of Advanced Manufacturing Technology, Vol. 18, 842-849.

[24] Saaty, T.L. (1994). How to make a decision: the analytic hierarchy process, Interfaces, Vol. 24, 19-43.

[25] Lu, M.H., Madu, C.N., Kuei, C.-H., Winokur, D. (1994). Integrating QFD, AHP and benchmarking in strategic marketing, Journal of Business \& Industrial Marketing, Vol. 9, No. 1, 41-50.

[26] Raharjo, H., Xie, M., Goh, T.N., Brombacher, A. (2007). A methodology to improve higher education quality using the quality function deployment and analytic hierarchy process, Total Quality Management \& Business Excellence, Vol. 18, No. 10, 1097-1115.

[27] Bañuelas, R., Antony, J. (2003). Going from six sigma to design for six sigma: an exploratory study using analytic hierarchy process, The TQM Magazine, Vol. 15, No. 5, 334-344. 